\title{
Small Pelagis Fisheries Productivity in Coast of the Sunda Strait of Banten Province
}

\author{
Ririn Irnawati \\ Indonesia Center of Excellence for \\ Food Security (I-CEFORY), UNTIRTA \\ (Local Food Innovation), \\ Banten, Indonesia \\ ririn.irnawati@untirta.ac.id \\ Hery Sutrawan Nurdin \\ Indonesia Center of Excellence for \\ Food Security (I-CEFORY), UNTIRTA \\ (Local Food Innovation), \\ Banten, Indonesia \\ herysutrawannurdin@gmail.com
}

\author{
Adi Susanto \\ Indonesia Center of Excellence for \\ Food Security (I-CEFORY), UNTIRTA \\ (Local Food Innovation)Banten, \\ Indonesia \\ adisusanto@untirta.ac.id
}

Fahresa Nugraheni Supadminingsih

University of Sultan Ageng Tirtayasa

Banten, Indonesia

fahresan@gmail.com

\author{
Dini Surilayani \\ Indonesia Center of Excellence for \\ Food Security (I-CEFORY), UNTIRTA \\ (Local Food Innovation), \\ Banten, Indonesia \\ dini.surilayani@untirta.ac.id \\ Asep Hamzah \\ University of Sultan Ageng Tirtayasa \\ Banten, Indonesia \\ asephamzah9@gmail.com
}

\begin{abstract}
Banten Province has a very strategic position because it has unique water characteristics because the borders are direct with the Indian Ocean and the Java Sea, and the mixing of water masses in the Sunda Strait. These conditions make the waters as a center of fishing activity, especially pelagic fish. The sustainable potential of pelagic fish in 2015 reached 49,576.11 tons. The development of pelagic fisheries in Banten still faces various challenges including fluctuations in fishing productivity. This study aims to determine the productivity of pelagic fisheries in the Sunda Strait. The study was conducted in May-August 2019 on the coast of the Sunda Strait by a survey method. The productivity of small pelagic fisheries is analyzed based on the productivity value of the fishing unit and the productivity of fishermen. The types of pelagic fish resources that become commodities and the main target of fishermen caught in Pandeglang Regency which are small pelagic fish, comprising mackerel, scad, yellowstripe scad, mackerel tuna and anchovy. The production volume of anchovy in Pandeglang Regency reaches $68 \%$ of the total small pelagic fish production, while mackerel has a contribution of $26 \%$. The average productivity of fishing units per year reaches $17,730 \mathrm{~kg}$. Annual productivity of fishermen reaches $4,426 \mathrm{~kg}$ with productivity per trip of $55 \mathrm{~kg}$. Small pelagic fisheries businesses in this region can still be maintained to improve the welfare of fishermen through the application of sustainable management principles.
\end{abstract}

Keywords: Anchovy, Pandeglang, productivity, small pelagic fish, Sunda strait

\section{INTRODUCTION}

Banten Province has abundant of potential of fish resources, with a very strategic position at the western end of the island of Java. The characteristics of Banten waters are very unique because they are directly bordered by the Indian Ocean in the southern region, the Java Sea in the north, and the mixing of water masses in the Sunda Strait in the west. This conditions make the waters of Banten Province fertile and become a center of fishing activity both for local fishermen and fishermen from areas around Banten [1]. The fish resources group which is quite abundant is pelagic fish with production volume in 2015 reaching $28,451.7$ tons or $67 \%$ of the total fish production [2].
The sustainable potential of pelagic fish in the waters of Banten Province in 2015 reached 49,576.11 tons [3] with the main production centers on the coast of the Sunda Strait especially in Labuan District and Sumur District. Pelagic fishing technology in this area is dominated by lift net, gill nets, boat seine and purse seine. Sunda Strait waters have a pelagic fishery potential of $35 \%$ of the potential of Banten Province with suboptimal utilization. The Sunda Strait is a potential fishing area for the whole year with the highest alleged productivity in2016 reaching 39,339-58,327 tons / $\mathrm{m}^{3}$ [4][5].

Pelagic fish is a commodity that has high economic value, so that its management and development can improve the regional economy, because it can increase income, as well as fulfillment of community nutrition and protein. Nevertheless, the development of pelagic fisheries in Banten still faces various challenges including those related to fishing productivity fluctuations. These problems require the attention of all fisheries stakeholders. In an effort to develop and utilize the potential of pelagic fisheries in the Sunda Strait, especially after the 2018 tsunami, the latest information on pelagic fisheries productivity is needed. This information is very important for the formulation of a pelagic fisheries management and development strategy on the coast of the Sunda Strait. This study aims to determine the productivity of pelagic fisheries in the Sunda Strait.

\section{METHOD}

The study was conducted in May-August 2019 in pelagic fisheries centers along the coast of the Sunda Strait in Banten Province. The main locations are Pandeglang Regency and Serang Regency. The Pandeglang Regency included the Sumur, Panimbang and Labuan Districts, while the Serang Regency study area is in the Cinangka District.

The research conducted by survey method. Research data collection is done through observation, in-depth interviews and literature study. The primary data include the number and types of fishing efforts, the number and types of catch, the number of fishing vessels and the number of fishermen. 
Pelagic fishery productivity in the coastal area of the Sunda Strait was analyzed based on the productivity value of fishing units and fishermen productivity. Fishing unit productivity is the ability of a fishing unit to produce catch per unit fishing time. The time of fishing referred to is per trip and per year. The formula for calculating fisheries productivity is as follows:

$$
\begin{gathered}
\text { Productivity of fishing unit per trip }=\frac{\text { number of catch in one year }(\mathrm{kg})}{\text { number of trip in one year }(\mathrm{trip})} \\
\text { Productivity of fishing unit per year }=\frac{\text { number of catch in one year }(\mathrm{kg})}{\text { number of fisining unit in } 1 \text { year (unit) }}
\end{gathered}
$$

Fisherman productivity is the ability of fishermen to produce catches per unit of time. The unit of time used is per trip and per year. The formula for calculating fisheries productivity is as follows:

$$
\begin{aligned}
& \text { Productivity of fisherman per trip }=\frac{\text { number of catch per trip }(\mathrm{kg})}{\text { number of fisherman per trip }(\mathrm{person})} \\
& \text { Productivity of fisherman per year }=\frac{\text { number of catch in } 1 \text { year }(\mathrm{kg})}{\text { number of fisherman in } 1 \text { year }(\text { person })}
\end{aligned}
$$

\section{RESULT AND DISCUSSION}

Types of pelagic fish resources that become commodities and the main target of fishermen catching in Pandeglang Regency are small pelagic fish, consisting of mackerel, scads, yellowstripe scad, mackerel tuna and anchovy. The fish landing centers in Pandeglang Regency are in the Labuan fishing port (FP), Sidamukti FP, Panimbang FP and Sumur FP. Labuan is the main center of mackerel landing with the main fishing gear are payang and purse seine. In addition, mackerel landing centers are also found at Sidamukti with purse seine as the main fishing gear. Panimbang and Sumur are anchovy landing centers in Pandeglang Regency with main fishing gear are set lift net, floating lift net, boat lift net and badak lift net. In 2018, the production of small pelagic fish in Pandeglang District reached 14,308 tons which were dominated by anchovies and mackerel as presented in Table I.

Table I. shows the production of small pelagic fish in Pandeglang Regency is dominated by anchovies with a production volume of nearly 10.000 tons. Anchovy is the main catch for fishermen in Panimbang and Sumur because it has a high economic value and has a relatively long fishing season. The Sunda Strait waters are potential fishing ground throughout the year, both in La Nina, normal and El Nino conditions [5]. The condition of Sunda Strait waters is dynamic and have a positive impact on the productivity of anchovy fishery in Pandeglang area [1]. This affects the volume of anchovy production in Pandeglang District which reaches $68 \%$ of the total small pelagic fish production in Pandeglang Regency. Meanwhile, mackerel has a contribution of $26 \%$. Other fish species only contribute less than five percent of the total small pelagic fish production as shown in Figure1.

TABLE I. PRODUCTION OF DOMINANT SMALL PELAGIC FISH (KG) IN KAB. PANDEGLANG IN 2018

\begin{tabular}{lrrrrr}
\hline Type of fish & \multicolumn{5}{c}{ Productivity volume $(\mathrm{kg})$} \\
\cline { 2 - 6 } & \multicolumn{1}{c}{ Labuan } & Sidamukti & Panimbang & \multicolumn{1}{c}{ Sumur } & \multicolumn{1}{c}{ Total } \\
\hline Mackerel & 2.061 .288 & 1.565 .209 & 1.105 & 55.243 & 3.682 .845 \\
Scads & 83.274 & 55.995 & 1.436 & 2.872 & 143.576 \\
Yellow & 91.064 & 102.319 & 5.116 & 6.139 & 204.638
\end{tabular}

Strip Scads

\begin{tabular}{lrrrrr} 
Mackarel & & & & & \\
Tuna & 371.255 & 222.753 & 6.188 & 18.563 & 618.759 \\
Anchovy & 5.795 & - & 3.650 .049 & 6.002 .925 & 9.658 .769 \\
Total & 2.612 .677 & 1.946 .276 & 3.663 .893 & 6.085 .741 & 14.308 .587 \\
\hline \multicolumn{4}{l}{ Source: Processed from the DKP Banten publication in 2019 and the results of the interview }
\end{tabular}

The production volume of pelagic fisheries is influenced by the number of fishing efforts and the availability of fish resources. The rate of exploitation of mackerel tuna in the Sunda Strait was the highest compared to other small pelagic (1) fish. The exploitation rate of mackerel tuna in 2014 reached 0.95 per year while mackerel has an exploitation rate of 0.6 per year [6]. The exploitation rate is still relevant to the percentage of small pelagic fish in 2018 which shows that the contribution of mackerel is higher than the mackerel tuna.

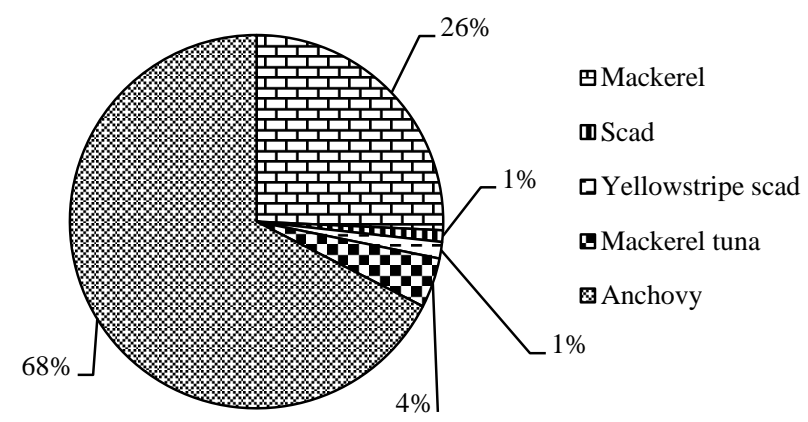

Fig. 1. Production of small pelagic fish in Pandeglang Regency in 2018.

The handling process and condition of anchovy landing are different from those of other pelagic fish landings. Anchovy has been boiled on a ship before landing on Panimbang and Sumur. Meanwhile, other pelagic fish are still landed in fresh form. Boiling on the ship is done to maintain the quality of anchovies remain good so the selling price remains high when it reaches the hands of consumers. The boiled anchovy is then dried to a certain water level and then sent to Jakarta. The condition of dried anchovy and mackerel landed in Pandeglang Regency is presented in Figure 3.

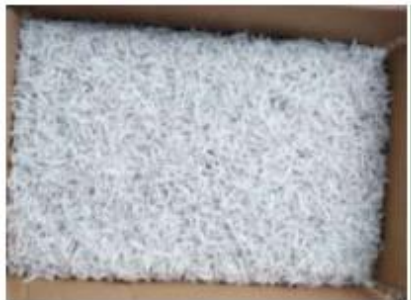

a) Anchovy

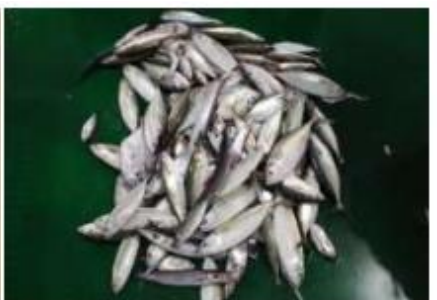

b) Mackerel
Fig. 2. The dominant small pelagic fish species in Pandeglang Regency

Pelagic fishing in the Sunda Strait waters in general can be grouped into two, namely fishing operations carried out during the day using boat seine and gillnet, and fishing operations conducted at night with light aids (light fishing). Gillnet and boat seine generally operate on a daily trip. However, if the catches do not cover operational costs, the length of fishing trip will increase to 2-3 days. The number of gillnet and boat seine trips in one month is between 15-20 days with an average number of fishing operation months of eight months. Meanwhile for the set lift net and the boat lift net, the number of trips in one month depends on the dark 
period of the moon. Nevertheless, generally fishermen of lift net operate between 15-18days.

Capture productivity is influenced by natural factors and human factors. Natural factors that have a significant influence include fish abundance, fishing season and oceanographic conditions. The human factor that contributes dominantly is the capacity of fishing vessel and fishing units and also the skills of fishermen. The dimensions of fishing gear, technical specifications of the fishing gear and the size of the vessel have a significant effect on the productivity of purse seine in Bone Regency. Catch productivity will increase higher when using purse seine which has a larger inner size and a higher vessel capacity [7].

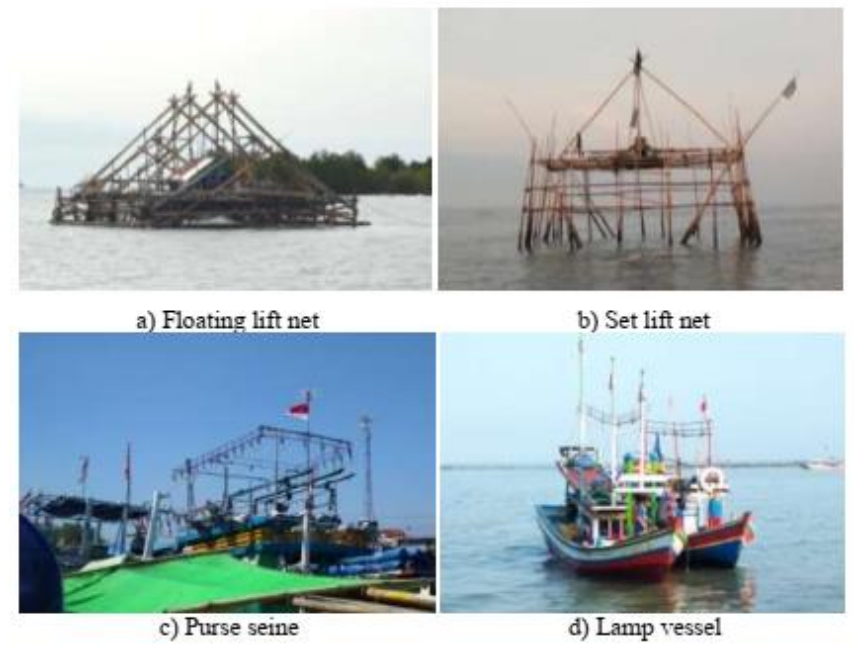

Fig. 3. Small pelagic fishing vessels in Pandeglang Regency.

The results of the calculation of the productivity of small pelagic fisheries conducted based on the number of fishermen and the number of trips for the Pandeglang Regency area indicate that the average productivity of fishing units per year reaches $17,730 \mathrm{~kg}$. Small pelagic fishermen are able to catch fish with annual productivity reaching $4,426 \mathrm{~kg}$ with productivity per trip of $54.73 \mathrm{~kg}$ as presented in Table II.

TABLE II. THE PRODUCTIVITY OF PELAGIC FISHERY IN THE SUNDA STRAIT

\begin{tabular}{clrc}
\hline No & \multicolumn{1}{c}{ Information } & Value & Unit \\
\hline 1 & Fisherman productivity per year & $4.426,35$ & $\mathrm{~kg}$ \\
2 & Fisherman productivity per trip & 54,73 & $\mathrm{Kg}$ \\
3 & Fishing unit productivity per trip & 161,18 & $\mathrm{~kg}$ \\
4 & Fishing unit productivity per year & $17.729,78$ & $\mathrm{~kg}$ \\
\hline
\end{tabular}

The varying size of the fishing vessel and the types of fishing gear used by small pelagic fishermen affect the final value of fishing productivity. In the purse seine vessel based in Labuan and Sidamukti, the productivity of fishing units per trip during peak season can reach two to four tons. But during the low season, its productivity dropped dramatically. In semi-industrial purse seine fisheries, ship productivity also decreased significantly. The highest productivity can reach 63 tons per trip, but when it is not the fish season the productivity becomes 13 tons/trip [8].

Sunda Strait waters still have potential fish resources to be utilized compared to the Java Sea which is already fully- exploited. This can be seen from the productivity value of small pelagic fishermen obtained. Fishermen in Pandeglang Regency have an average productivity of $54 \mathrm{~kg}$ per trip. Meanwhile, the productivity of purse seine in the Sunda Strait based on Lempasing fishing port is also higher at 100 $\mathrm{kg}$ per trip [9]. The pelagic fisheries productivity is higher when compared to the productivity of small pelagic purse seine fishermen in the Java Sea. The productivity of small pelagic purse seine fishermen operating in the Java Sea with a landing base at Muncar fishing port was only $31 \mathrm{~kg}$ per trip [10]. This means that pelagic fisheries in this area can still be maintained to improve the welfare of fishermen through the application of sustainable management principles.

\section{CONCLUSION}

The average productivity of pelagic fishing units per year reaches $17,730 \mathrm{~kg}$. Fisherman productivity per year is 4,426 $\mathrm{kg} /$ year; fisherman productivity per trip54.73 $\mathrm{kg}$ and fishing unit productivity per trip $161.18 \mathrm{~kg}$.

\section{ACKNOWLEDGMENT}

The research is funded by Islamic Development Bank (IsDB) through University of Sultan Ageng Tirtayasa research grant (The Development of Sultan Ageng Tirtayasa University as Center of Excellence in Food Security for Nation Competitiveness).

\section{REFERENCES}

[1] R. Irnawati, D. Surilayani, A. Susanto, A. Munandar, and A. Rahmawati, "Potential yield and fishing season of anchovy (Stolephorus sp.) in Banten, Indonesia," AACL Bioflux, vol. 11, pp. 804-809, Juni 2018

[2] Dinas Kelautan dan Perikanan Provinsi Banten. 2016. DKP Dalam Angka. Serang: Dinas Kelautan dan Perikanan Provinsi Banten.

[3] Dinas Kelautan dan Perikanan Provinsi Banten. 2016. Kajian Potensi Perikanan Tangkap di Perairan Provinsi Banten. Serang: Dinas Kelautan dan Perikanan Provinsi Banten.

[4] S. G. Akmal, A. Fahrudin, and S. B. Agus, "Spatial Distribution of Fish Abundance in Sunda Strait," Jurnal Pengelolaan Perikanan Tropis, vol. 1, pp. 25-31, December 2017.

[5] Y. Nurkhairani, Supriatna, and D. Susiloningtyas, "Wilayah potensi ikan pelagis pada variasi kejadian ENSO dan normal di Selat Sunda," Jurnal Geografi Lingkungan Tropik, vol. 2, pp. 52-63, Februari 2018.

[6] W. Octoriani,A. Fahrudin, and M. Boer, "Exploitation rate of fisheries resources which caught by purse seine in Sunda Strait," Marine Fisheries, vol. 6, pp. 69-76, May 2015.

[7] A. Rumpa, Najamuddin, and S. A. Farhum, "Influence design fishing gear and purse seine vessel capacity on productivity catch fish in the District of Bone," Jurnal IPTEKS PSP, vol. 4, pp. 144 - 154, October 2017.

[8] S. B. Atmaja, M. Natsir, and A. Kuswoyo, "Analisis upaya efektif dari data vessel monitoring system dan produktivitas pukat cincin semi industri di Samudera Hindia," JurnalPenelitian Perikanan Indonesia, vol. 17, pp. 177-184, September 2011

[9] S. Alhuda, Z. Anna, and I. Rustikawati, "Analysis of productivity and business performance purse seine fishermen at Lempasing coastal fishing port, Bandar Lampung," Jurnal Perikanan Kelautan, vol. 7, pp. 30-40, Juni 2016.

[10] T. Perkasa, D. Wijayanto, and A. D. P. Fitri, "Analysis of productivity purse seine gardan and purse seine slerek with fishing base on Muncar coastal fishing port, Banyuwangi Regency, East Java,'Journal of FisheriesResources Utilization Management and Technology, vol. 5, pp.102-110, January 2016. 